\title{
Pedagogisk credo - barnehagelærerstudenters refleksjoner om verdier og pedagogisk ledelse
}

Av Ingunn Reigstad, førstelektor, NLA Høgskolen

\section{Abstrakt}

Barnehagelæreren har et samfunnsmandat som krever bevissthet om holdninger og verdier som ligger til grunn for det pedagogiske arbeidet. Forståelse for samfunnsmandatet er en sentral del av utdanningen. Det pedagogiske credoet utvikles gjennom de tre årene i utdanningen og det gis veiledning individuelt og i grupper. Hensikten med å utvikle sitt pedagogiske credo er blant annet å bli klar over egne verdier og holdninger i møte med samfunnsmandatet. Studien ønsker å belyse dette gjennom problemstillingen: På hvilken måte bidrar arbeidet med pedagogisk credo i barnehagelærerutdanningen til studentenes forståelse av verdiene i samfunnsmandatet og av pedagogisk ledelse? Data i denne studien bygger på tekstanalyse av 43 «pedagogiske credo» fra tredje-års studenter i barnehagelærerutdanningen ved NLA Høgskolen. Arbeidet med pedagogisk credo beskrives som en skriftliggjøring av egne refleksjoner omkring studentens pågående danningsprosess fra student til å bli en profesjonell yrkesutøver.

Analysen viser at flertallet av studentene har en grunnleggende forståelse for pedagogisk leders ansvar for å realisere samfunnsmandatets verdier og innhold. Som framtidige ledere vektlegger barnehagelærerstudentene respekt, omsorg og likeverd som de mest sentrale verdier. Disse verdiene er også viktige i samfunnsmandatet. Deres beskrivelse av verdiene som ledere av barn og medarbeidere presenteres og drøftes.

Nøkkelord: pedagogisk credo, verdier, barnehagelærerutdanning, samfunnsmandat, refleksjon 


\section{Abstract}

ECEC teachers have a societal mandate that requires awareness of the values and attitudes on which the pedagogical work in ECEC is founded. Understanding this mandate will be a crucial part of the ECEC teacher education. The pedagogical creed is developed during the three years of education and guidance is given individually and in groups. The purpose of developing their pedagogical creed is, among other things, to become aware of their own values and attitudes in the face of the societal mandate. This study seeks to illuminate this through answering the question: In what way does the writing of students' pedagogical creed in an ECEC teacher education contribute to their understanding of the values in the societal mandate for pedagogical leadership? Data in this study are based on qualitative text analysis of 43 pedagogical creeds from third year students at NLA University College in Norway. The writing of a pedagogical creed is described as a process of reflections in an ongoing development from student to a professional ECEC teacher. The study enlightens how the development of a pedagogical creed in ECEC teacher-education might strengthen students` reflections and awareness of their own values as coming ECEC teachers. The text analysis show that most students have a good understanding of their responsibility as ECEC teacher to implement the values and goals of the societal mandate. As coming leaders, the ECEC students emphasize respect, care, and equity as their most central values. These values are also core values in the societal mandate. Their descriptions of these values as coming ECEC teachers will be presented and discussed.

Keywords: Pedagogical creed, values, ECEC teacher-education, societal mandate, reflection

\section{Innledning}

Barnehagelæreren forvalter et samfunnsmandat som krever fagkunnskap, etisk refleksjon og profesjonelt skjønn (Hennum \& Østrem, 2016). Forståelsen av samfunnsmandatet og hvilken betydning det har for egen yrkes- 
utøvelse vil være en sentral del av studentens danning i utdanningen. Barnehagens samfunnsmandat uttrykker barnehagens oppdrag. Det er, «i samarbeid og forståelse med hjemmet, å ivareta barnas behov for omsorg og lek og fremme læring og danning som grunnlag for allsidig utvikling. Lek, omsorg, læring og danning skal ses i sammenheng» (Barnehageloven, 2005, $\$ 1$ ). Dette arbeidet skal bygge på grunnleggende verdier i kristen og humanistisk arv og tradisjon. (Barnehageloven, 2005, $\$ 1$ ).

Da vil det være viktig at barnehagelærerutdanningen legger til rette for arbeid der studentene kan utvikle et bevisst forhold til hvilke holdninger og verdier som legges til grunn for barnehagens pedagogiske arbeid (Hennum \& Østrem, 2016, s. 67). Nasjonale retningslinjer for barnehagelærerutdanningen uttrykker at studentene skal utvikle «evne til å analysere egne holdninger og egne og andres handlinger gjennom kritisk refleksjon, aleine eller i et profesjonsfellesskap, og slik utvikle selvstendig handlingskompetanse og evne til å ta egne valg» (Universitet-, og høgskolerådet (UHR), 2018, s. 5).

For å støtte denne utviklingen har barnehagelærerutdanningen ved NLA Høgskolen valg at studenten skal utvikle sitt eget personlige pedagogiske credo. I det pedagogiske credoet beskriver studentene hva som er viktig for dem og hvilke verdier og holdninger de ønsker skal prege deres framtidige pedagogiske arbeid (Akslen og Sæle, 2015, s. 24). Gjennom arbeid med pedagogisk credo kan barnehagelærerstudenten reflektere over fellesverdiene som uttrykkes i samfunnsmandatet, og forholdet mellom fellesverdiene og studentens individuelle verdier. Forståelsen for hvilke verdier som preger egne handlinger kan være ulik i en studentgruppe. Noen har høy bevissthet både om egne verdier og verdiene som uttrykkes i samfunnsmandatet. Andre uttrykker at det er vanskelig å forstå at verdier, holdninger og handlinger hører sammen. Denne studien søker å besvare spørsmålet: På hvilken måte bidrar arbeidet med pedagogisk credo i barnehagelærerutdanningen til studentenes forståelse av verdiene i samfunnsmandatet og av pedagogisk ledelse? 


\section{Arbeid med pedagogisk credo i barnehagelærer- utdanningen}

Studenten begynner arbeidet med sitt personlige pedagogiske credo allerede første året i utdanningen. Det videreutvikles i andre studieår og avsluttes i kunnskapsområdet Ledelse, samarbeid og utviklingsarbeid i tredje studieår. Første studieår fokuseres det på studentens egen bakgrunn og erfaring og refleksjoner omkring hvordan denne har påvirket studentens personlige utvikling. Videre arbeides det med hvilke individuelle verdier og holdninger studenten ønsker å arbeide ut ifra, og hvordan disse korresponderer med barnehagens verdigrunnlag. Studenten uttrykker også sitt syn på barnet, og på lek og læring. I andre studieår arbeides det videre med det pedagogiske credoet, og nå beskriver studenten hvilke fagområder og arbeidsmåter i barnehagen som hun brenner for. Studentens refleksjoner omkring foreldrenes rettigheter i oppdragelsen av barnet og foreldresamarbeid skrives nå også inn $\mathrm{i}$ credotekstene. Tredje studieår fokuseres det på studentens rolle som leder i barnehagen, og hun skriver om sine verdier og holdninger i kollegasamarbeidet og som leder av det pedagogiske arbeidet.

Gjennom prosessen med å skrive og utvikle sitt pedagogiske credo gis det veiledning fra skolens lærere. Første året gis det individuell veiledning, mens det andre og tredje studieår gis veiledning i små grupper. Tekstene leveres inn hvert år og kommenteres også skriftlig av veileder. Studenten har ved hver innlevering anledning til å gjøre endringer i deler som tidligere er skrevet. Ved muntlig eksamen i kunnskapsområdet Ledelse, samarbeid og utviklingsarbeid tredje studieår presenterer studenten sitt pedagogiske credo slik det er ved utdanningens slutt. Da fokuseres det spesielt på studentens verdier og holdninger som kommende leder i barnehagen. Slik arbeides det for å holde bevisstheten om og refleksjonen rundt egen danning oppe gjennom hele studiet.

\section{Teori}

For å besvare forskningsspørsmålet vil jeg i teoridelen sette søkelys på hva som menes med verdier og hvordan disse danner et grunnlag for våre hold- 
ninger og handlinger. Videre vil jeg utdype hva et pedagogisk credo er, og hvordan refleksjon kan skape forståelse hos den enkelte student.

\section{Verdier}

Alt pedagogisk arbeid som utføres i barnehagen bygger på verdier. Verdier kan forstås ut fra både en formålsrasjonalitet, altså at handlingen vurderes ut fra målet med handlingen eller en verdirasjonalitet, som vil si at handlingen vurderes ut fra verdiene til den som handler (Dale, Gilje \& Lillejord, 2011, s. 107-132). I fortsettelsen vil jeg presentere begge disse perspektivene. Ut fra formålsrasjonalitet sier Kirkhaug (2018, s. 15) at «verdier kan betraktes som virkemidler som brukes av samfunn, organisasjoner, grupper og enkeltpersoner for å orientere seg og ha standarder for holdninger og handlinger». Barnehagens samfunnsmandat slik det uttrykkes i formålsparagrafen (Barnehageloven, 2005, \$1) er et slikt virkemiddel. Det presiseres i Rammeplanen (Kunnskapsdepartementet [KD], 2017, s. 1) at «barnehagens verdigrunnlag skal formidles, praktiseres og oppleves i alle deler av barnehagens pedagogiske arbeid». Da er det avgjørende at barnehagelærerne har en grunnleggende forståelse for hva verdier er, hvordan verdiene preger barnehagehverdagen og slik «bidra til at barna kan forstå felles verdier og normer som er viktige for fellesskapet» (KD, 2017, s. 21).

Den enkeltes oppmerksomhet og forstålse av verdienes plass både i samfunnet og eget liv varierer. Verdiene er ikke medfødt, men utvikles og læres gjennom barndommen. Kirkhaug (2018, s. 52) refererer til Jung (1967) når han sier at «forestillinger som er skapt i barndom og oppvekst, har en tendens til å forbli referanser for holdninger og handlinger hele livet». Verdier kan dermed ses på som et anker for vår identitet, et sted der vi finner feste (Moen, 2015). Både Moen og Sagberg kan forstås ut ifra et verdirasjonalitetsperspektiv, og Sagberg $(2017$, s. 15) sier at «ut fra verdiene våre tar vi valg og handler». Verdier ses ofte på som noe positivt, et gode vi vil verne om eller søke å oppnå (Moen, 2017 s. 26), men Kirkhaug (2018, s. 23) presiserer at verdier er situasjonsbetingede verktøy - en verdi er aldri bare positiv eller negativ - alt avhenger av betingelser og formål. Han sier videre at verdier er grunnleggende sosiale ordensverktøy, mentale kart og kompass og kriterier for sortering og vurdering av ulike handlingsalternativer (Kirkhaug, 2018, 
s. 22). Verdier knyttes ofte sammen med holdninger. Holdning er en innstilling eller et syn i en viss sak. Holdningsbegrepet er alltid relasjonelt: holdning er noe en har til noe eller noen (Asheim, 1997, s. 22). Holdningsbegrepet kan hjelpe oss til å få fram mer konkrete aspekter ved verdibegrepet. Holdningene våre viser seg $\mathrm{i}$ handlingene.

\section{Pedagogisk credo og refleksjon}

For å styrke den enkelte barnehagelærerstudents forståelse av forholdet mellom verdier i samfunnsmandatet og deres individuelle verdier, er det viktig at utdanningen finner metoder som kan bidra til å utvikle studentenes refleksjoner og forståelse. Skriving av eget pedagogisk credo mener jeg kan være en slik metode.

Benevnelsen pedagogisk credo kan gi assosiasjoner både til det pedagogiske og religiøse fagspråket. Det pedagogiske arbeidet består i å legge til rette for en hverdag preget av lek, læring, danning og utvikling. Dette må skje i samspillet mellom barn, medarbeidere og foreldre. Begrepet credo kommer fra latin og betyr «jeg tror». Det handler om hva barnehagelærerne har tro på i arbeidet sitt, hva som er viktig for dem, hvilke mål de har og hva de brenner for (Gilje, 2001, s. 64). Begrepet lærerens credo vil også ligge tett opptil lærerens grunnholdninger, grunnsyn, ideologi, ethos, selvforståelse, implisitte tenking og praksisteori (Gilje, 2001, s. 64). Pedagogisk grunnsyn defineres av Lillemyr \& Søbstad (1993, s. 87) som «den virkelighetsoppfatning, de verdier og holdninger som ligger til grunn for pedagogisk virksomhet». Gunnestad (2014, s. 36) sier at det pedagogiske grunnsynet består av sentrale elementer som virkelighetsoppfatning, livssyn, menneskesyn, synet på læring og samfunnssyn. Dette må avklares både hos den enkelte yrkesutøver og i hele personalgruppa. Akslen \& Sæle (2015, s. 24) definerer pedagogisk credo slik: «Studentenes pedagogiske credo kan vi dermed samlet hevde utgjør studenters subjektive oppfatninger, holdninger, verdier og følelser knyttet til det framtidige pedagogiske fagfelt og yrkesliv».

Utviklingen av studentens pedagogiske credo er en del av danningsprosessen som barnehagelærer. Palmer (1998, s. 1) uttrykker det ved å si «we teach who we are», og peker dermed på den personlige siden ved yrkesutøvelsen. Sagberg $(2017$, s.16) uttrykker noe av det samme når han sier at 
«Gode lærere er i stand til å se sammenhengen mellom hvem de er som person og hvem de er som lærere». Pedagogisk credo utvikles gjennom individuelle og kollektive refleksjoner. Slik blir begrepet refleksjon sentralt.

Det etymologiske opphavet til begrepet reflektere finner vi i det latinske «reflectere», der «re» betyr «tilbake, på ny, igjen» og «flectere» står for «bøye tilbake» (Gundersen, 2019). Torunn Klemp (2013) sier at «re» betyr at det er noe som kommer tilbake, noe som man ser på eller går inn i på nytt, og at refleksjon faktisk krever noe å speile eller bryne tankene mot. Videre sier hun at «flectere» innebærer at det er noe man skal gjøre noe med, bøye og bende på, plukke fra hverandre. Reflektere handler om å utfordre tatt-forgitt-oppfatninger. Å reflektere betyr dermed også å «utfordre». Grüters (2011, s. 74) presenterer i sitt PhD- arbeid en grundig gjennomgang av refleksjonsbegrepet og sier at «refleksjon er en dialektisk og spekulativ prosess i bevisstheten som i et dialogisk møte med en tekst fører til ny erfaring og ny kunnskap» (Grüters, 2011, s. 90). Hun viser til Thomas Aquinas og sier at han var den første til å ta refleksjonsbegrepet i bruk om tankens tilbakeskuende bevegelse. Hun sier at han knytter refleksjonsbegrepet til vår evne til å betrakte og vurdere oss selv, altså selvrefleksjon (Grüters, 2011, s. 74). Slike selvrefleksjoner legges det til rette for, både individuelt og i fellesskap, som en del av veiledningen som gis i tilknytning til utviklingen av studentens pedagogiske credo.

\section{Metode}

Det empiriske materiale for studien består av pedagogiske credo fra 43 studenter i 3. studieår i barnehagelærerutdanningen ved NLA Høgskolen. De pedagogiske credoene er levert som et arbeidskrav i kunnskapsområdet Ledelse, samarbeid og utviklingsarbeid. Studentene har gitt skriftlig samtykke til at materialet kan brukes i forskning.

Tekstene er analysert med tanke på å bringe fram hvilke verdier studentene uttrykker er viktige for dem i det pedagogiske arbeidet med barn og kolleger. Jeg har gjort en analyse av tekstdata (Ringdal, 2018). I analysen har jeg brukt både en kvalitativ og en kvantitativ tilnærming. Den kvantitative delen av analysen innebar registrering av ord i studenttekstene. Helt konkret 
har jeg sett etter de samme begrepene som finnes i barnehagelovens formålsparagraf: respekt for menneskeverdet og naturen, åndsfrihet, nestekjærlighet, tilgivelse, likeverd og solidaritet, omsorg, trygghet, tilhørighet og anerkjennelse, demokrati, mangfold og gjensidig respekt, likestilling, bærekraftig utvikling, livsmestring og helse, og talt opp forekomsten av disse. Videre har jeg kodet studentenes beskrivelser av disse verdiene og gjort en kvalitativ innholdsanalyse. Ringdal (2018, s. 268) definerer kvalitativ innholdsanalyse som «en metode for subjektiv tolking av tekstdata ved bruk av systematisk klassifisering og koding for å identifisere tema og mønster». I presentasjonen av hvilke verdier studentene vektlegger gjengis studentenes beskrivelser og forståelse av verdiene. Når studentene omtaler verdier som er viktige for de, peker de på at disse er viktige i arbeidet med barna og medarbeidere. Verdier som nevnes av flest studenter er: respekt (26), omsorg (25), likeverd (23), nestekjærlighet (17) og trygghet og medvirkning (16 hver). Jeg vil gå nærmere inn i studentenes beskrivelser av respekt, omsorg og likeverd fordi disse verdiene er sentrale i formålsparagrafen, og nevnes i et flertall av de pedagogiske credoene.

I analyse av tekstdata stiller en seg spørsmål om autentisitet, troverdighet, representativitet og tolking. Studentenes tekster er anonymisert før analyse for at ikke tolkingen skal påvirkes av kjennskap til studentene. Spørsmålet om bruk i forskning kom etter at de pedagogiske credoene var levert og godkjent som arbeidskrav. Det ble gjort for at ikke innholdet skulle påvirkes av vissheten om at credoet skulle benyttes i forskning. Kullet besto av 53 studenter, og 43 av disse gav samtykke til bruk i forskning. Alle disse pedagogiske credoene er analysert.

\section{Resultat og drøfting}

I resultatpresentasjon og drøfting fokuseres det først på studentenes beskrivelser av hvordan de forstår holdninger og handlinger som kan knyttes til verdiene respekt, omsorg og likeverd. Videre ses det på hvordan barnehagelærerstudentene presenterer hvordan de ønsker at disse verdiene skal prege arbeidet deres som pedagogiske ledere i barnehagen. Og til slutt drøftes forholdet mellom barnehagens formålsparagraf og studentenes verdier. 


\section{Barnehagelarerstudentenes verdier}

Respekt holdes fram som en viktig verdi av mer enn halvparten av studentene. De utdyper sin forståelse av begrepet ved å bruke ord som: «føle seg verdsatt; forståelse for det som er annerledes; se den andre; gode relasjoner; hensyn til kulturforskjeller; respekt for menneskeverdet og naturen; alltid tenke på barns beste; åpenhet; forståelse og toleranse; alle mennesker skal respekteres og anerkjennes; fremme mangfold og gjensidig respekt».

I studentenes utdyping av respekt knyttes begrepet til deres holdninger til medarbeidere, foreldre og barna. De peker på hvordan respekt skal vises i praksis. Studentene knytter det til å se den andre, verdsette og anerkjenne. Anerkjennelse handler både om menneskets ukrenkelige verdi, og at den enkelte har et utviklingspotensial (Skoglund \& Åmot, 2012). Studentenes beskrivelser av anerkjennelse og respekt kan også ses i sammenheng med at de vektlegger åpenhet, forståelse og toleranse. I vårt flerkulturelle samfunn er det helt nødvendig at respekt også handler om å ta hensyn til kulturforskjeller, ha forståelse for det som er annerledes og fremme mangfold. Flere studenter trekker fram at mangfold skal verdsettes og kan være en styrke i fellesskapet.

Studentenes refleksjoner og beskrivelser av hvordan de forstår begrepet kan forstås som en styrke for yrkesutøvelsen fordi studentene operasjonaliserer begrepet. Respekt er relasjonelt og en holdning man kan oppleve at andre har til en selv, men også en holdning som viser seg i barnehagelærerens møte med barn, foreldre og medarbeidere. Hvordan kan så barnehagelærerutdanningen arbeide med bevisstgjøring av respekt som en viktig verdi? En mulighet kan være at en i enda større grad fokuserer på hvordan respekt viser seg i samspillet studentene imellom og i møte med lærere. Utdanningen må legge til rette for mange arenaer der studentene må samarbeide, være avhengig av hverandres deltakelse og verdsette ulikheter. Ved å erfare og sette ord på hvordan respekt viser seg i praksis kan den enkeltes bevissthet styrkes. Arbeidet med pedagogisk credo kan også være et viktig verktøy. Gjennom veiledning i grupper der studentene må reflektere over egne verdier og samfunnsmandatets verdier, kan forståelse og bevissthet utvikles. Deres individuelle forståelser «kastes tilbake» av medstudenter og lærere, og gjennom kollektive prosesser kan den enkelte «utfordres» (Klemp, 2013). Verdiene ses 
på fra ulike synsvinkler og settes ord på av den enkelte student. Prosessen styrkes også gjennom skriftliggjøring i det pedagogiske credoet.

Omsorg er en av verdiene som kobles tett til lek, læring og danning i barnehagelovens formålsparagraf (Barnehageloven, 2005, \$1). Omsorg nevnes av over halvparten av studentene og forklares i credoene som: "profesjonell omsorg; tålmodighet; ta vare på og forstå de svakeste; kjærlighet; sensitivitet; oppmerksomhet; nestekjærlighet; tilhørighet og anerkjennelse; gi barna tro på seg selv; støtte barnet i dets identitetsprosess; ivareta alle barn; gi barn positiv selvoppfatning; alle må få den støtte og hjelp de har behov for; gi barna mestringsfølelse og god selvfølelse; gi livsmestring og god helse; være raus og tilstede; vise barnet enorm kjærlighet og omsorg og sette seg inn i det enkelte barn sin situasjon; vise empati».

Studentene peker på mange sider ved omsorgsbegrepet og viser forståelse for at omsorg handler om å sørge for, ta vare på eller vise omtanke for (Tholin, 2013). Det gjelder både barnets fysiske og psykiske behov. Studentene uttrykker at omsorgen skal være profesjonell og preget av kjærlighet, empati og sensitivitet. Studentenes beskrivelser av omsorg inneholder alle de fire elementene som Tholin (2003, s. 48-49) peker på: det relasjonelle, et handlingselement, er knyttet til følelser, og et moralsk og yrkesetisk element. Mange studenter vektlegger også at omsorg er knyttet til barnets identitetsutvikling. Slik peker de på at barns mestring er viktig for utvikling av et godt selvbilde og god helse. Rammeplanen sier at "Barnehagen skal gi barna mulighet til å utvikle tillit til seg selv og andre» (KD, 2017). Slik viser de forståelse for et helhetlig syn på barnets utvikling.

Likeverd pekes også på som viktig av over halvparten av studentene og beskrives på følgende måter: «åndsfrihet; støtte barns undring og vitebegjær - også av religiøs karakter; alle er verdifulle; synliggjøre den enkeltes plass i fellesskapet; se fordomsfritt på den andre og anerkjenne den andre; tilhørighet; alle er like mye verdt; alle betyr noe; skape relasjoner der barna føler seg godtatt; respekt for menneskeverdet; rett til å uttrykke sin etniske og kulturelle bakgrunn; ha en forståelse for andre mennesker og ikke være dømmende; forebyggende arbeid mot mobbing; se ressurser i mangfold; lære barna å være inkluderende; sette alle barn på lik linje; kulturforståelse og respekt for andres kulturer». 
Likeverd og respekt er verdier som begge uttrykker vår holdning til medmennesker. Studentene benytter ulike uttrykk for å beskrive at alle barn er like mye verd uavhengig av mangfold og variasjoner i egenskaper (Emilsen, 2015 , s. 22). Studentene ønsker å arbeide for at alle kan bli godtatt, føle tilhørighet og bli inkludert, og viser forståelse for at kulturelle og religiøse forskjeller kan skape forskjellsbehandling. Studentene uttrykker et ressursperspektiv på mangfold og setter ord på hvordan de ønsker å arbeide for å hindre mobbing. Fokuset settes på det enkelte barn, og studentene sier at inkludering er noe en må arbeide aktivt med i en gruppe. Det er ikke noe som kommer av seg selv.

Verdiene respekt, omsorg og likeverd er sentrale i formålsparagrafen (Barnehageloven, 2005, \$1), og Rammeplanen (KD, 2017, s. 1) presiserer at «barnehagens verdigrunnlag skal formidles, praktiseres og oppleves i alle deler av barnehagens pedagogiske praksis». Skriftliggjøringen og refleksjoner i veiledningssituasjonen kan være til hjelp slik at studentene utfordres til selvrefleksjon (Grüters, 2011) - hvabetyr disse verdiene for meg i praksis? Kirkhaug $(2018$, s. 21) sier at «verdier er bevisste eller kognitive når de aktivt refereres til som grunnlag for beslutninger og handlinger». I de pedagogiske credoene utfordres studentene nettopp til å begrunne sine handlinger ut fra verdier som er viktige både for samfunnet og dem selv. Ved å «bøye og bende» (Klemp, 2013) på begrepene kan studentene få en bedre forståelse for hvordan verdiene kan vise seg i møte med barn, foreldre og medarbeidere. Akslen \& Sæle (2015) siterer i sin bok en tidligere student ved NLA Høgskolen som sier at «ved å skrive ned egne tanker blir en mer bevisst på sine verdier og holdninger» (s. 15).

\section{Studentenes tanker om verdier og ledelse}

I sine pedagogiske credo skriver studentene også om kollegasamarbeid og sitt syn på ledelse. Det som skiller seg ut som viktig for de fleste, er de relasjonelle forholdene i medarbeiderfellesskapet. Gotvassli (2013, s. 34) sier at ledelse er å arbeide sammen med andre, og studentene uttrykker forståelse for dette og sier at de ikke kan lede alene.

I de pedagogiske credoene er det 9 studenter som henviser til «den gylne regel» som rettesnor for arbeidet. Den finner vi i Matt. 7.12. Bibel 2011. 
«Alt dere vil at andre skal gjøre mot dere, det skal også dere gjøre mot dem. For dette er loven og profetene». Ved å vise til dette bibelverset peker disse studentene på seg selv som rollemodeller og forbilder for barn og voksne. En sier: «Ved valg vi tar kan verdiene merkes». Og en annen sier: «Jeg vil være en leder som leder ikke bare med ord og i planer og strukturer, men også med livet mitt».

Mange andre studenter nevner også at det er viktig for dem å være rollemodeller/forbilder. Noen knytter modelleringen til en måte å fremme ønsket atferd på. En student skriver det slik: «Jeg ønsker å være et godt forbilde både for medarbeiderne og barna i barnehage. Jeg ønsker å være en som får medarbeiderne med meg, en som kan motivere og inspirere».

Mange peker på at de som ledere vil møte den enkelte ansatte ut ifra situasjonen, og tilpasset medarbeidernes kompetanse. Følgende utsagn finnes: "ta hensyn til at alle er forskjellige og har ulik kompetanse; ut ifra hvilken kompetanse medarbeiderne mine har i ulike oppgaver vil jeg finne en lederstil som passer inn; tillit skapes i en relasjon der det er sammenheng mellom kompetanse og forventninger; bruke medarbeidernes kompetanse og gi passe med støtte og utfordringer». Flertallet av studentene viser forståelse for at medarbeidere må møtes ut fra sin kompetanse og viser til teorier av Hersey \& Blanchard (1988) slik disse presenteres i Gotvassli (2019, s. 56-57). De viser forståelse for at forholdet mellom støtte og styring må tilpasses den enkelte medarbeider, og at ikke alle kan behandles likt. Mange studenter vektlegger medarbeidernes opplevelse av mestring, og at dette er viktig for den enkeltes trivsel og utvikling. Studentene beskriver det blant annet slik: «gi medarbeiderne mestringsfølelse; legge til rette for at mine kollegaer får blomstre med sine oppgaver; alle skal få oppleve utvikling og mestring og bidra med sin kompetanse».

Holdningene som studentene viser gjennom flere av de foregående utsagnene kan tolkes som uttrykk for omsorg, respekt og likeverd. Omsorgen for medarbeiderne uttrykkes ved studentenes beskrivelser av hvordan de ønsker å sørge for den enkelte, ta vare på dem og vise omtanke ut fra den enkeltes behov. Respekten viser seg ved å anerkjenne dem og tone seg inn på medarbeidernes perspektiver og behov. Medarbeiderne skal møtes der de er, deres kompetanse skal verdsettes, og mestring og videre utvikling skal vektlegges. St.meld. 41. Kvalitet i barnehagen (Kunnskapsdepartementet, 2008-2009) 
peker på at barnehagens kvalitet er avhengig av de ansatte og deres holdninger og handlinger. Ved å uttrykke likeverd i relasjon til medarbeiderne viser studentene forståelse for at alle ansatte er like viktige og kan utfylle hverandre.

Studentenes beskrivelser av sin forståelse av samfunnsmandatet som kommende ledere

Barnehagelærernes oppgave er å realisere det samfunnsmandatet som er gitt gjennom barnehageloven og rammeplanen (KD, 2017, s. 16). Alle studentene viser i sine pedagogiske credo til en eller flere verdier som beskrives i formålsparagrafen (Barnehageloven, 2005, \$1). 22 studenter siterer formålsparagrafen direkte og utrykker at arbeidet som skal utføres i barnehagen skal bygge på disse verdiene. En student uttrykker det slik: «Mitt ansvar er å gjøre meg kjent med barnehageloven og rammeplan for barnehagens innhold og oppgaver slik at jeg kan lede personalet mot en felles visjon». En annen sier: «En leder skal sørge for at samfunnsmandatet blir ivaretatt og at barnehagen møter kravene». En tredje student sier: «Vi må være i endring for å oppfylle rammeplanen sine mål». Flere studenter viser at de er oppmerksomme på hvilket ansvar de har ved å vise til pedagogisk leders oppgaver og ansvar, som også vektlegger ansvaret for å oppfylle formålsparagrafens mål (KD, 2017, s.16).

Et flertall av studentene viser i sine pedagogiske credo at de har en grunnleggende forståelse av barnehagelærerrollen og samfunnsmandatet. Hennum \& Østrem (2018) peker på slik bevissthet som en forutsetning for å være barnehagelærer. Profesjonsrollen utøves i spenningen mellom formålsrasjonell og verdirasjonell handling. Dale, Gilje og Lillejord (2011, s.120) sier med utgangspunkt i Webers teori om rasjonalitet og handling, at alt pedagogisk arbeid tar utgangspunkt i overordnede utdanningspolitiske og verdimessige fastlagte mål, og at det er nødvendig å tenke igjennom hvilke midler som er best egnet til å nå disse målene. Da blir det avgjørende for barnehagelærerens utøvelse av yrket at de forstår verdirasjonelle handlinger som et middel til å oppfylle intensjonene i formålsparagrafen. Verdiene må settes ord på slik at de kan forstås av alle i barnehagen. Uten at verdiene gis innhold, kan de bli instrumentelle og ikke danne grunnlag for kritisk refleksjon. Des- 
suten må barnehagelæreren også kunne vurdere om handlingene er egnet til å nå formålsparagrafens mål. Verdirasjonaliteten er praksisbasert og har en hverdagslogikk. Gjennom arbeidet med å reflektere over forholdet mellom fellesskapets verdier og egne verdier kan forståelsen for hvordan verdiene bør praktiseres i barnehagens praksisfellesskap, styrkes.

Alle studentene knytter verdier og ledelse sammen i tekstene sine, og uttrykker hva de ønsker å vektlegge i arbeidet med barna og som ledere av medarbeidere. Noen studenter uttrykker også i sitt pedagogiske credo at utdanningen har satt søkelys på sammenhengen mellom egne verdier og holdninger og dermed utviklet dem som kommende barnehagelærere. En student uttrykker det slik: «Barnehagelærerutdanningen har hjulpet meg til å bli mer bevisst mine verdier og holdninger, og har hjulpet meg i utviklingen av mitt faglige perspektiv». En av studentene som tydeligst knytter ledelse og verdier sammen skriver det slik:

Som leder står verdier som gjensidig respekt, tillit og ærlighet sterkt hos meg. Som leder mener jeg det er viktig å skape felles verdigrunnlag for alle i barnehagen. En barnehage der personalet har en felles forståelse for barnehagens holdninger og verdier bør være et mål.

En annen sier: «Som framtidig barnehagelærer har jeg et overordnet ansvar for å handle etter lærerprofesjonens etiske plattform og samfunnsmandat». Videre uttrykker en det slik: «Ved å arbeide tett sammen på tvers av erfaring og utdanning og ha en felles forståelse for hvilke verdier vi står for». En annen student legger vekt på anerkjennelse som en viktig verdi og sier: «En god leder tar vare på personalgruppen sin, er støttende og oppmuntrende. Det er viktig å anerkjenne de voksne i barnehagen også». Til slutt tar jeg med et sitat som peker på egenskaper hos en leder som studenten ønsker å vektlegge i eget arbeid: «Egenskaper en god leder bør ha er ydmykhet, ærlighet og være rettferdig, lyttende og engasjert».

Det er en styrke at studentene knytter verdier og ledelse sammen i credotekstene sine fordi handlinger og holdninger preges av våre verdier. Noen knytter ledelse til sine individuelle verdier og beskriver disse med andre ord enn de som benyttes i Barnehageloven (2005). Jeg finner ikke at noen studenter uttrykker verdier eller holdninger som strider mot barnehagens formålsparagraf. For en del studenter var det uvant og nytt å skulle reflektere 
og sette ord på verdier som var viktig for dem. Men gjennom arbeidet med sine pedagogiske credo, og veiledning individuelt og i grupper, kunne de få støtte til økt bevissthet om både egne og fellesskapets verdier.

\section{Avslutning}

Barnehagelærerrollen krever fagkunnskap, etisk refleksjon og profesjonelt skjønn (Hennum \& Østrem, 2016). Disse tre komponentene må være til stede i barnehagelærerutdanningen, og ved NLA Høgskolen har vi valgt pedagogisk credo som et redskap for å utvikle studentenes etiske refleksjoner. Etisk refleksjon handler om våre handlinger og holdninger i møte med barn, foreldre og medarbeidere. «Barnehagen skal bidra til at barna kan forstå felles verdier og normer som er viktige for fellesskapet» (KD, 17 s. 21), og da er det viktig at utdanningen også legger til rette for refleksjon omkring felles verdier. Analyse av studentenes pedagogiske credo i tredje studieår viser at flertallet knytter sitt framtidige arbeid i barnehagen opp til sentrale verdier i formålsparagrafen (Barnehageloven, 2005). De fleste beskriver respekt, omsorg og likeverd som viktige verdier for dem som ledere av barna og medarbeiderne. Gjennom sine pedagogiske credo reflekterer de omkring verdienes handlings-, og holdningskomponent som de beskriver med egne ord. Skriftliggjøring av tanker kan skape selvrefleksjoner og større forståelse for verdienes betydning for arbeidet som pedagogisk leder, og det viser studien at arbeidet med pedagogisk credo bidrar til.

Som vist i studien setter en rekke studenter klare ord på sin forståelse av samfunnsmandatet og hvilket ansvar de har for at formålsparagrafen og barnehagens verdigrunnlag skal «formidles, praktiseres og oppleves i alle deler av barnehagens pedagogiske arbeid» (KD, 17 s. 1). I sine pedagogiske credo forklarer de hvordan de ønsker at sentrale verdier som respekt, omsorg og likeverd skal erfares av barna i barnehagehverdagen. De peker på at de som kommende pedagogiske ledere har ansvar for at medarbeiderne sammen må arbeide for å skape en felles plattform bygd på barnehagelovens verdier og grunnlag. Flere gir også uttrykk for at arbeidet med skriftliggjøring av eget pedagogisk credo har vært en bevisstgjøring og refleksjonsprosess som har forberedt dem til yrket. 
Arbeidet med pedagogisk credo har vist at for noen studenter er det fremdeles vanskelig ved studiets slutt å sette ord på og forstå verdienes betydning for arbeidet som barnehagelærere. Men hos flertallet av studentene finner vi $ø \mathrm{kt}$ refleksjon og evne til å relatere verdier, holdninger og handlinger til hverandre. I sine pedagogiske credo viser de fleste at verdiene er blitt bevisste for dem ved at de aktivt refereres til som grunnlag for beslutninger og handlinger de ønsker å fremme som pedagogiske ledere.

\section{Referanser}

Akslen, Å.N. \& Sæle, O.O. (2015). Pedagogisk grunnlagstenkning, yrkesdanning og credo. I: Å.N. Akslen, \& O.O. Sæle, (red.). Pedagogisk grunnlagstenkning og credo. Fra student til barnehagelarer. Oslo: Universitetsforlaget.

Asheim, I. (1997). Hva betyr holdninger? Studier i dydsetikk. Oslo: Tano Aschehoug.

Barnehageloven (2005). Lov om barnehager. https://lovdata.no/dokument/NL/lov/2005-06-17-64

Dale, E.L., Gilje, N. \& Lillejord, S. (2011). Gjennomføring av utdanningsreformer i kunnskapssamfunnet. Oslo: Cappelen Damm akademisk.

Emilsen, K. (2015). Likestilling og likeverd i Norge. I: K. Emilsen (red.) Likestilling og likeverd i barnehagen (s. 21-37). Bergen: Fagbokforlaget.

Gilje, J. (2001). I spenningsfeltet mellom krav og credo. I. T. Berge (red.). Slipp elevene løs! Artikler med søkelys på larerrollen (s. 63-79) Oslo: Gyldendal akademisk.

Gotvassli, K.Å. (2013). Ledelse i barnehagen. Oslo: Universitetsforlaget.

Gotvassli, K.Å. (2019). Ledelse i barnehagen. 2. utg. Oslo: Universitetsforlaget.

Grüters, R. (2011). Refleksjon i blogg: en hermeneutisk studie av refleksjon og dens tekstlige og retoriske manifestasjon $i$ en ny type skrive- og arkiveringsteknologi. Doktorgradsavhandling, Norges teknisk-naturvitenskapelige universitet: Trondheim.

Gundersen, D. (2019). Reflektere. I: Store norske leksikon. Hentet 31. mars 2020 fra https://snl.no/reflektere 
Gunnestad, A. (2019). Didaktikk for barnehagelarere. En innforing. Oslo: Universitetsforlaget.

Hennum, B.A, \& Østrem, S. (2016). Barnehagelareren som profesjonsutøver. Oslo: Cappelen Damm akademisk.

Kirkhaug, R. (2018). Verdibasert ledelse. Oslo: Universitetsforlaget.

Klemp, T. (2013). Refleksjon - hva er det, og hvilken betydning har den i utdanning til profesjonell lærerpraksis? Uniped (36):42-58. https://doi.org/10.3402/uniped.v36i1.20957

Kunnskapsdepartementet. (2017). Rammeplan for barnehagen. Innhold og oppgaver. Forskrift om rammeplan for barnehagens innhold og oppgaver. Hentet fra https://www.udir.no

Lillemyr, J.F \& Søbstad, F. (1993). Didaktisk tenking i barnehagen. Oslo: Tano.

Moen, K. (2017). Mot til å formidle verdier-også i et kulturelt mangfold. I: S. Sagberg (red.). Mot til à vare barnehagelarer. Verdier som omdreiningspunkt (s. 25-51) Bergen: Fagbokforlaget.

Palmer, P.J. (1998). The Courage to Teach. Exploring the Inner Landscape of a Teacher's life. San Francisco: Jossey-Bass.

Ringdal, K. (2018). Enhet og mangfold. Samfunnsfaglig forskning og kvantitativ metode. (4. utg.) Bergen: Fagbokforlaget.

Sagberg, S. (2017). Introduksjon. I: S. Sagberg (red.). Mot til à vare barnehagelerer. Verdier som omdreiningspunkt. Bergen: Fagbokforlaget.

Skoglund, R.I. \& Åmot, I. (2012). Anerkjennelsens kompleksitet i pedagogiske institusjoner. I: R.I. Skoglund \& I. Åmot (red.). Anerkjennelsens kompleksitet $i$ barnehage og skole (s. 17-40) Oslo: Universitetsforlaget.

Kunnskapsdepartementet (2009). Kvalitet $i$ barnehagen. (St.meld. nr. 41 (2008-2009)). Hentet fra https://www.regjeringen.no/no/dokumenter/stmeld-nr-41-2008-2009-/id563868/

Tholin, K.R. (2003). Etisk omsorg i barnehagen og skolen. Oslo: Abstrakt Forlag.

Tholin, K.R. (2013). Omsorg i barnehagen. Bergen: Fagbokforlaget.

Universitets- og høgskolerådet (2018). Nasjonale retningslinjer for barnehagelererutdanning. https://www.uhr.no/_f/p1/i8dd41933-bff1-433c-a82c$2110165 \mathrm{de} 29 \mathrm{~d} /$ blu-nasjonale-retningslinjer-ferdig-godkjent.pdf 